\title{
Open Ye the Gates: Procedure for Returning the Torah to the Ark
}

\author{
Joseph H. Prouser
}

\section{She'eilah}

Worshippers at Temple Emanuel of North Jersey ask: When returning the Torah at the conclusion of the Shabbat/Yom Tov Torah service, when is the most appropriate time to open the Ark?

\section{Teshuvah}

Seder Hachnasat Ha-Torah, the service for returning the Torah Scroll to the Ark following its public reading on Shabbat or Yom Tov, begins (among Ashkenazim) with Ashrei (Ps 145, etc.). This is followed by Psalm 148:13-14 (עללו את יהליו.), and a procession carrying the Torah Scroll through the congregation while reciting either Psalm 29 on Shabbat, or Psalm 24 on weekdays. Upon approaching the Ark to return the Torah, a collection of biblical verses is

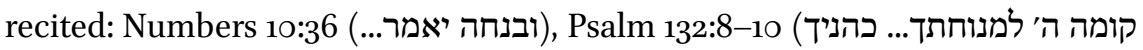


השיבנו) (חיים היא...דרכיה דרכי נועם... and the concluding verse of Lamentations 5:21).

On ordinary weekdays, the procedure is briefer. Ashrei is recited only after returning the Torah to the Ark; there is frequently no procession beyond moving the Torah Scroll directly to the Ark; the weekday Psalm (24) is commonly read silently.

1 Compare Ps 132:8-10 and the parallel text in 2 Chr 6:41-42. 


\section{Historical Development}

These procedures are of relatively late development. Ismar Elbogen writes: "Concerning the Returning (כניסה, הכנסה) of the Torah, we learn nothing from the ancient sources, nor does Soferim mention it."2 Similarly, Rabbi Jeffrey Hoffman indicates that Tractate Soferim "gives details of the service for taking out the Torah only. Discussion of the service to return the Torah is not found until the early siddurim." 3 The dearth of classical instruction on the liturgical procedure for returning the Torah to the Ark may reflect the fact that early synagogues generally lacked a permanent Ark as an architectural feature of the sanctuary. ${ }^{4}$ The Torah Scroll, at the conclusion of public worship, was removed to a neighboring home or building for safekeeping. ${ }^{5}$

\section{Conflicting Instructions}

Contemporary siddurim offer conflicting instructions as to when, during Seder Hachnasat Ha-Torah, the Ark is to be opened in anticipation of receiving the Torah Scroll. Siddur Sim Shalom ${ }^{6}$ indicates that the Ark is to be opened following Ashrei and before the verses from Psalm 148. The same directive is found in the High Holiday Prayer Book edited by Rabbi Morris Silverman, Machzor Hadesh Yameinu, edited by Rabbi Ronald Aigen, ${ }^{7}$ and the new Koren Siddur, edited by British Chief Rabbi Lord Jonathan Sacks.

The Reconstructionist Movement's Kol Haneshamah Daily Prayerbook, instructs that the Ark be opened at Uvnucho Yomar, following the procession with the Torah. Rabbi Hayim Halevy Donin unambiguously confirms this procedure for opening the Ark for the return of the Torah: "While the Prayer Leader is carrying the Torah back to the Ark, the one so honored should step

2 Ismar Elbogen, Jewish Liturgy: A Comprehensive History, trans. Raymond Scheindlein (Philadelphia: Jewish Publication Society; New York: Jewish Theological Seminary, 1993), 160.

3 Jeffrey Hoffman, "The Ancient Torah Service in Light of the Realia of the Talmudic Era," Conservative Judaism 42, no.2 (Winter 1989-1990): 47n.

4 See Ruth Langer, "From Study of Scripture to a Reenactment of Sinai: The Emergence of the Synagogue Torah Service," Worship 72, no. 1 (1998): 43-67.

5 See b. Soțah 38b; Shulhan Arukh, ợ 149.

6 Siddur Sim Shalom for Shabbat and Festivals, 1998 edition. The 1985 edition edited by Rabbi Jules Harlow provides no such instruction.

7 Rabbi Aigen's siddur was published by Congregation Dorshei Emet, the Reconstructionist Congregation of Montreal. 
up ahead and open the Ark. The precise moment for doing so is when the passage Uvnocho Yomar is reached."

Many siddurim, even those which note the opening of the Ark at the beginning of the Torah Service, provide no explicit instruction as to when the Ark is to be opened at the service's conclusion. Among these are the Bokser, Birnbaum, Silverman, and Artscroll/RCA siddurim, Hertz's Authorised Daily Prayerbook, The New Union Prayerbook, Siddur Mishkan Tefillah, Siddur Rinat Yisrael, Siddur Or L'Yisrael, The New Mahzor, Mahzor Lev Shalem, the Harlow Machzor, Siddur Hadesh Yameinu, and, as indicated above, Rabbi Jules Harlow's original edition of Siddur Sim Shalom. In his Guide to Jewish Religious Practice, Rabbi Isaac Klein specifies only when the Ark is to be closed-following the pastiche of verses ending with Lamentations 5:21—but not when the Ark is opened in the first place.

These conflicting and ambiguous logistical instructions have led to (and perhaps find their origin in) a variety of local practices. Congregations variously open the Ark before Yehallelu, at an unspecified point during the Torah procession and its accompanying Psalm, upon conclusion of that Psalm irrespective of where in the Sanctuary the procession has reached, or upon approaching the Ark prior to Uvnucho Yomar.

\section{Opening the Ark at Yehallelu}

Opening the Ark at Yehallelu, as per the Silverman Machzor, the revised Siddur Sim Shalom and the Koren Siddur, has an obvious drawback. The individual leading the service, those carrying any additional Torah Scroll(s), and those joining the procession (frequently the rabbi and congregational leaders) with the intention of thereby honoring the Torah, must turn their back on the open Ark (and any Torah Scrolls it still contains) and walk away! Additionally, it is proper for worshippers to face the Torah throughout the procession, requiring them, as sanctuary architecture and individual seating dictate, to turn their backs on the open Ark for much of that procession as well. As Rabbi David Fine writes of this procedure, "once the processional passes a worshipper, the worshipper has to choose between turning his/her back on the Torah in the processional or on the ark." ${ }^{\prime 9}$

8 Hayim Halevy Donin, To Pray as a Jew (New York: Basic Books, 1980), 49.

9 Personal correspondence, November 26, 2013. Rabbi Fine instructs his congregation, Temple Israel of Ridgewood, NJ, to open the Ark only when the processional has "made its final turn and is heading back to the bima" - as this permits worshippers to face both the Torah 
The principle of facing the Torah, and the gravity attached to this expression of deference, is articulated by Maimonides:

מצוה לייחד לספר תורה מקום ולכבדו ולהדרו יותר מדאי, דברים שבלוחות הברית הן ולפו

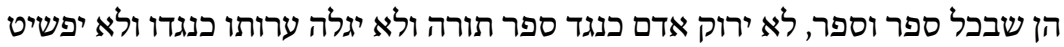

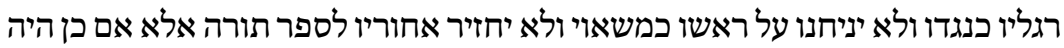

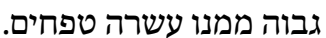

It is a Mitzvah to assign a place for the Torah Scroll to be kept, and to accord it extreme honor and deference. The words on the Tablets of the Ten Commandments are in every Torah Scroll. One must not spit before a Torah Scroll, nor indecently expose oneself before it, nor spread one's legs before it, nor carry it on one's head as if it were a burden, nor may one turn his back to the Torah Scroll, unless it is at an elevation of ten handbreadths above the person. ${ }^{10}$

Why do such venerable liturgical authorities as Rabbi Morris Silverman (a decisive force in the shaping of non-Orthodox congregational worship in North America and beyond) and Chief Rabbi Sacks prescribe a procedure with such obvious spiritual disadvantages? At least three possibilities present themselves: a. Perhaps they did not consider opening the Ark in this manner a disadvantage at all. Rabbi David Small, Rabbi Silverman's current successor as spiritual leader of Emanuel Synagogue in West Hartford, Connecticut, ${ }^{11}$ reports that his congregation maintains its longstanding practice, indicated in the Silverman Machzor, of opening the Ark at the beginning of the Torah procession (once the procession has descended the Bimah). Rabbi Small suggests that the open Ark reinforces the "numinous" nature of the moment, alerting the congregation to both the destination of the Torah and the high sanctity of the moment. These stated advantages out-

and the Ark simultaneously. Correspondence from Rabbis Joel Pitkowsky (Congregation Beth Sholom of Teaneck - home to numerous JTs faculty members), and Randall Mark (Shomrei Torah: Wayne Conservative Congregation) affirm the same liturgical policy.

10 Mishneh Torah, Hilchot Sefer Torah 10:10. Ten handbreadths is approximately 40 inches. The Torah Scrolls in the Ark of Temple Emanuel of North Jersey rest on a surface 77 inches above the sanctuary floor: less than "ten handbreadths above" anyone exceeding 37 inches in height!

11 During my 13 years as Rabbi of Congregation B'nai Sholom in Newington, CT, I had frequent occasion to worship at Emanuel Synagogue, especially throughout the year of saying Kaddish for my mother, of blessed memory. As a young member of Kadimah and UsY, I attended many functions at Emanuel and was there honored with my first Hagbah! 
weigh the concern about turning one's back on the Ark, according to Rabbi Small. Notwithstanding this choreographic calculus, the congregation maintains a strict policy prohibiting, e.g., Bar Mitzvah photographs being taken on the Bimah with the subjects' backs turned to the open Ark, as this is, under normal circumstances, deemed an act of disrespect.

b. Rabbi Sacks' instruction that the Ark be opened at Yehallelu may reflect an architectural reality more common in Orthodox synagogues: the location of the Bimah with Torah Reader's table in the center of the sanctuary. For Hachnasat Ha-Torah, the procession with the Torah moves forward, directly from the centrally located Bimah to the Ark at the front of the sanctuary. Those in the procession face the open Ark throughout this process. This rationale does not entirely resolve the issue for those worshippers seated between the Bimah and the Ark, who must still turn to face the Torah as it approaches, thereby turning their backs toward the open Ark.

c. It is very common for the Ark to be opened at Yehallelu during weekday morning or Shabbat Minchah services. On these occasions, as indicated above, the process of returning the Torah to the Ark is relatively brief, and it is common to omit any actual procession through the sanctuary ... to recite Psalm 24 quickly and silently ... and to move the Torah directly to the Ark. At no point during this weekday process is it necessary either for those accompanying the Torah, nor the congregation, to turn away from the Ark (unless there is a central Bimah-see Irb, above). A weekday Ark opening at Yehallelu is thus entirely appropriate. It seems likely that this feature of the weekday service was transferred by some to the Shabbat and Holiday liturgy without regard for the inadvertent slight to the Ark and the Torah Scrolls which - by virtue of the procession which is added to the more elaborate Torah Service conducted on those festive occasions-it entails. Rabbi David Wise, of Hollis Hills Jewish Center in Queens (where he shares the pulpit with Cantor Sol Zim, who has had such a profound impact on the musical expression of synagogue liturgy), thus reports that his congregation opens the Ark (in a smaller chapel) at Yehallelu on weekdays, and delays the opening (in the main sanctuary) to a later point on Shabbat and Holidays.

If opening the Ark at Yehallelu (or at the outset of the Torah procession) is designed to evoke a sense of the "numinous," such a determination is based on a subjective judgement regarding both the spiritual impact of an open Ark and the liturgical moments meriting such a measure. Recitation of the Shema is certainly a moment rife with the numinous (though it is our custom to remain seated, with the Ark, accordingly, shut). The silent Amidah-both its prescribed text and the private prayers and personal petitions we add- 
demand a particular awareness of God's presence ... and the congregation is already standing. Similarly, Barchu, Yizkor, Shochen Ad, etc ... all partake of the "numinous." Invoking this justification for opening the Ark for the Torah procession, to the exclusion of these other impactful moments of prayer, is unconvincing ... particularly since it compromises customary standards of deference to the Torah Scroll.

If Rabbi Sacks' prescription of an Ark opening at Yehallelu assumes, as a condition of its permissibility, a centrally located Bimah, obviating (or, at least, minimizing) the need to turn one's back on either the Torah or the open Ark, such a liturgical policy should be abandoned when these conditions to not obtain.

If opening the Ark at Yehallelu is a practice inadvertently imported from the weekday service (when there is nothing in the liturgical choreography to contraindicate this timing), the distinctive Torah procession of Shabbat and Yom Tov demand that we reassess the timing of the Ark opening. Following the weekday procedure on Shabbat results in an entirely avoidable affront to the honor of the Ark. It is a practice grounded in error.

\section{Aggadic Perspective}

Though halachic texts governing the ceremonial return of the Torah to the Ark are few, a "charming Talmudic legend"12 suggests an early link between opening Ark doors and the recitation of Psalm 24 (as during the Torah procession on weekday festivals or, indeed, ordinary weekdays):

כשבנה שלמה את בית המקדש ביקש להכניס ארון לבית קדשי הקדשים, דבקו שערים

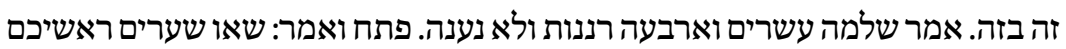

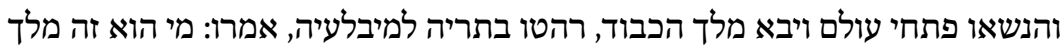

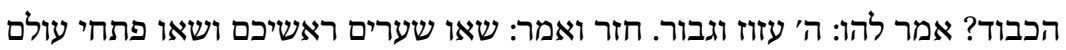

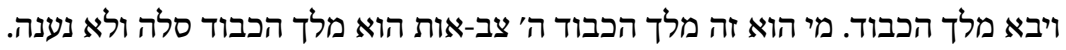

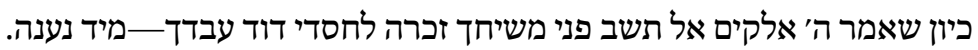

When Solomon built the Holy Temple, he wanted to bring the Ark into the Holy of Holies, but the doors of the sacred chamber clung to each other and remained closed. Solomon recited twenty-four expressions of

12 Max Arzt, Justice and Mercy: Commentary on the Liturgy of the New Year and the Day of Atonement (New York: Burning Bush Press, 1963), 157. 
praise, ${ }^{13}$ but he was not answered. He then recited ' $\mathrm{O}$ gates, lift up your heads! Up high, you everlasting doors, so the King of Glory may come in!'14 They pursued him to swallow him up, ${ }^{15}$ saying, 'Who is the King of Glory?'16 He answered them, 'The Lord, mighty and valiant!'17 He then said further: 'O gates, lift up your heads! Lift them up high, you everlasting doors, so the King of Glory may come in! Who is the King of Glory? The Lord of Hosts, He is the King of Glory,'18 and still he was not answered. But when he said, 'O Lord God, do not reject ${ }^{19}$ Your anointed ones; remember the loyalty of Your servant David, ${ }^{20}$ he was answered immediately. ${ }^{21}$

The parallels between this Aggadic text and Seder Hachnasat Ha-Torah are striking. Both involve a ceremonious process by which a ritual object of ultimate holiness and covenantal significance (the Ark of the Covenant; the Torah Scroll) is brought to its sanctified depository (The Temple's Holy of Holies; the Synagogue's Holy Ark). Each involves recitation of Psalm 24, following an earlier liturgy. Solomon's introduction of the Ark to the Holy of Holies culminates in recitation of 2 Chronicles 6:42, while Hachnasat Ha-Torah concludes with that Scriptural context's close literary parallel in the Book of Psalms, with which it shares significant, identical phrases:

2Chronicles 6:41-42

Psalm 132:8-10

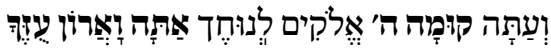

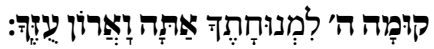

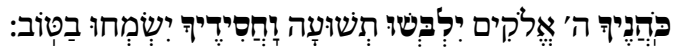

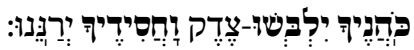

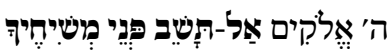



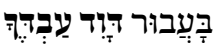

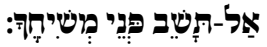

13 Identified variously as a reference to $1 \mathrm{Kgs} 8$ or to the blessings recited in conjunction with a fast-See Rashi ad loc. See also Steinsaltz ad loc.

14 Ps 24:7.

15 Apparently thinking Solomon was blasphemously referring to himself as the King of Glory.

16 Ps 24:8a.

17 Ps $24: 8$ b.

18 Ps 24:9-10.

19 Literally, "Do not turn away the face of Your anointed ones."

$20 \quad 2 \mathrm{Chr} 6: 42$.

21 b. Šabb. 3 oa. 
It is instructive that the doors to the Holy of Holies open for Solomon only following his recitation of Psalm 24 and only upon his recitation of 2 Chronicles

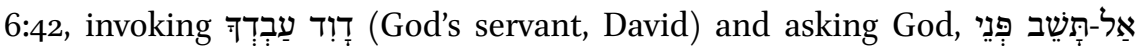
ממשׁיחיָּ (not to reject His anointed). The mosaic of verses with which our Torah Service concludes includes the more poetic variants of these very Scriptural phrases in Psalm 132. The Talmudic narrative appears to illustrate an early Seder Hachnasat Ha-Torah of roughly the same form preserved in our own current practice. Indeed, the aggadic text remains intelligible only if the opening of the doors to the Holy of Holies directly paralleled the liturgical function of the Chronicles verse and its psalmodic recension in Psalm 132 as "the precise moment"22 — even at this early stage in the development of the Torah Serviceat which the synagogue $\mathrm{Ark}^{23}$ was opened in order to receive the returning Torah Scroll: following the procession with the Torah and in conjunction with the concluding Biblical verses_-in contemporary practice, that is, beginning with Uvenucho Yomar.

\section{Conclusion}

Opening the Ark for Hachnasat Ha-Torah prior to (or even during) the procession with the Torah Scroll is to be avoided. It requires those leading the congregation in prayer, together with the worshippers they serve, to turn their backs either on the open Ark and any remaining Torah Scrolls it contains or on the Torah being carried in procession itself. This represents a forbidden affront to the Torah included by Maimonides in the same class as spitting, indecent exposure, coarse or unseemly personal carriage, and rough handling of the Scroll in the manner of ordinary burdens and baggage. Those contemporary siddurim that include instructions to open the Ark at Yehallelu either erroneously copy the weekday procedure - contraindicated by the liturgical changes unique to the Shabbat/Yom Tov liturgy — or assume specific synagogue architecture that minimizes but does not entirely avoid this offense ... yet which is rarely found in North American, non-Orthodox sanctuaries. Assertion of a subjective sense of the "numinous" or efforts to create a heightened spiritual ambience should not be given precedence over the clear halachic prohibition articulated by Maimonides ... violation of which is so easily avoided.

22 Donin, To Pray as a Jew.

23 As this architectural feature was introduced to the ancient synagogue. See Section I, at n. 4 , above. 
The proper point in Seder Hachnasat Ha-Torah for the opening of the Ark is only following the Torah procession and the concomitant singing of the prescribed Psalm. This was the practice of the congregation of my youth, ${ }^{24}$ of the Jewish Theological Seminary Synagogue ${ }^{25}$ under the leadership of Rabbi Saul Lieberman, of blessed memory, and reflects the precedent of the Talmudic age suggested in the Aggadah, discussed above, regarding Solomon and the doors of the Holy of Holies.

Rabbi Hayim Donin Halevy was correct: ${ }^{26}$ "The precise moment" for opening the Ark to return the Torah "is when the passage Uvnocho Yomar is reached."27

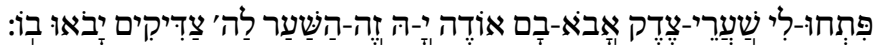

\section{Bibliography}

Arzt, Max. Justice and Mercy: Commentary on the Liturgy of the New Year and the Day of Atonement. New York: Burning Bush, 1963.

Donin, Hayim Halevy. To Pray as a Jew. New York: Basic Books, 1980.

Elbogen, Ismar. Jewish Liturgy: A Comprehensive History. Translated by Raymond Scheindlein. Philadelphia: Jewish Publication Society; New York: Jewish Theological Seminary, 1993.

Jeffrey Hoffman, "The Ancient Torah Service in Light of the Realia of the Talmudic Era." Conservative Judaism 42, no. 2 (Winter 1989-1990): 41-48.

Langer, Ruth. "From Study of Scripture to a Reenactment of Sinai: The Emergence of the Synagogue Torah Service." Worship 72, no. 1 (1998): 43-67.

24 Congregation B'nai Israel of Northampton, Massachusetts, under the religious leadership of Rabbi Asher Bar-Zev. This was also the practice of my father-in-law, Rabbi William Horn of the Jewish Community Center of Summit, NJ, and of Rabbi Martin Cohen, of the Shelter Rock Jewish Center on Long Island. Rabbi Cohen, a prolific author and liturgist, and long-time editor of Conservative Judaism, the academic journal of the Seminary and the Rabbinical Assembly, writes (in private correspondence): "That has been the practice in every shul I can recall being in."

25 It was my great privilege to serve Rabbi Lieberman as Seminary Synagogue gabbai for a number of years, during my undergraduate and rabbinical school tenure at JTs, a position I held at the time of Rabbi Lieberman's passing in 1983 .

26 As is the Reconstructionist Movement's Siddur Kol Haneshamah, see Section II above.

27 Donin, To Pray as a Jew, 49. 